differentialis passes through the last moult.

\section{Phoet aliotes.}

P. nebrascencis Thos.-Four specimens from Ford county, two of each variety $(P . n$. nebrascencis and $P . n$. volucris). Structural characteristics conform well with the description, except that in three of the four cases the fastigium is plainly sulcate. The other specimen $-P$. n. nebrascencis corroborated the description of Scudder. Prosternal spine not "erect" but slightly recumbent. Extremity of male abdomen only feebly clavate.

In the short winged variety $P . n$. nebrascencis, the two specimens at hand show marked variation in tegmina; alike in width, they differ in length, and in the form of distal extremity. The specimens agree in size, but tegmina are six and nine $\mathrm{mm}$. in length respectively. The shorter tegmina end more abruptly and the apex is more acute than in the longer wing.

Two males of each variety from Ford Co., July.

\title{
THE CLEAR-WINGED SPECIES OF THE OEDIPODINE GENUS MESTOBREGMA.
}

BY SAMUEL H. SCUDDER, CAMBRIDGE, MASS.

Most of the described species of the genus Mestobregma, like the type of the genus, have the wings distinctly crossed mesially by a fuscous band of greater or less width. In one species, however, $M$. kiowa Thom., the wings are pellucid, except for the fuscous veins and for the occasional faint clouding of the wings at the normal point for the band, or the heavier infuscation of the cross-veins in this region.

In the collections brought from the Pacific coast by Mr. A. P. Morse, are three species of the genus with wings showing at most no greater indication of a cross-band than in the species mentioned; indeed one of them is that species, which has never before been record- ed from west of Utah. They were found in successively more southern regions. The broad-winged form, $M$. kiozera, was obtained only in northern California near Mt. Shasta. The narrow-winged species occurred, one, $M$. hyalinum, in the San Joachin valley from the latitude of San Francisco to that of Los Angeles, the other, $M$. rosaceum, from the southern edge of the San Joachin valley to Yuma, Arizona.

The species may be separated as follows :-- -

Table of the clear-zinged species of Mestobregma.

$a^{1}$. Median carina of pronotum nearly obliterated between the sulci, here no 
more prominent than the lateral canthi of the scutellate disk beside it; process of metazona a little obtusangulate, rarely rectangulate; contrasted markings of tegmina confined to the costal field; wings relatively narrow, twice or more than twice as long as broad; hind tibiae yellow, occasionally faintly tinged with glaucous.

$b^{1}$. Front lobe of median carina of pronotum not prominent; lower posterior corner of lateral lobes distinctly angulate in female; wings pellucid, but with the basal half or less roseate, sometimes with feeble indications of a transverse band beyond by the broader infuscation of the cross-veins.

rosaceum.

$b^{2}$. Front lobe of median carina of pronotum distinctly cristate; lower posterior corner of lateral lobes well rounded in both sexes; wings wholly pellucid except for the apical infuscation of some of the anterior veins, with no signs of a transverse band.

hyalinum.

$a^{2}$. Median carina of pronotum crested between the sulci, here forming a distinctly rounded lobe; process of metazona rectangulate or subrectangulate; contrasted markings of tegmina crossing the discoidal as well as the costal field; wings relatively broad, distinctly less than twice as long as broad; hind tibiae blue.

kiowa.

\section{Mestobregma rosaceum sp. nov.}

Ferrugineo-testaceous, much marked with fuscous. Head salient, ferrugineo-testaceous, in the male paler than in the female and also often marked above with longitudinal fuscous stripes, and with a slender transverse line between the eyes, also found in the female; fastigium of vertex brief, deeply sulcate, particularly in the male, with a distinct median carina, the sharp margins of the fastigium continuous with the margins of the deeply sulcate frontal costa, which is narrow, slightly expanded at the ocellus, and broadens a little below; eyes prominent, particularly in the male; anterınae a little ( $\vec{\delta}$ ) or considerably ( $q$ ) shorter than the hind femora, testaceous annulate with fuscous or the reverse. Pronotum hardly longer than broad, mesially a little constricted, above of the color of the head, the lower portions of the lateral lobes clay-yellow, margined above with black fading into fuscous or ferruginous, the disk more or less (in the male conspicuously) marked with short longitudinal fuscous stripes, often with flavous interspaces; median carina no more elevated on the prozona than on the metazona or than the canthi of the scutellum, which is not at all pronounced; process of metazona a little obtusangulate; lower margin of lateral lobes with a distinct posterior depending denticulation in the female, the angle subrectangulate and rounded in the male. Tegmina very long and subequal, feebly maculate throughout, but with the contrasted markings not very marked and confined to the costal field, which is mostly fuscous with a pale cinereous spot just beyond the widest part; wings fully twice as long as broad, pellucid with fuscous veins and the basal half or less tinged with rosaceous, the costal margin infuscated beyond the middle, and sometimes the indications of a mesial cross-band in the deeper infuscation of the cross-veins. Hind femora cinereous marked with fuscous, and especially with two fuscous spots above, at and beyond the middle; hind tibiae pale yellow, occasionally a little embrowned, especially beneath.

Length of body, $\delta, 16 \mathrm{~mm} .,+, 25 \mathrm{~mm}$.; antennae, $\delta, 9 \mathrm{~mm}$., + , ro $\mathrm{mm}$.; tegmina, 
ริ, $19.5 \mathrm{~mm} .$, $+27 \mathrm{~mm}$; hind femora, $\delta$, Io $\mathrm{mm}$., $q, \mathrm{r} 3 \mathrm{~mm}$.

I9 $\delta$, I I + . Tehachapi, Cal., Aug. 2; Palm Springs, Cal., July I3; and Yuma, Ariz., July 7 (Morse).

\section{Mestobregma hyalinum sp. nov.}

Cinereo-testaceous, heavily marked with fuscous, occasionally wholly embrowned. Ilead salient, dull testaceous, more or less infuscated or punctate with fuscous above, especially in the female, and usually with a transverse fuscous line between the eyes; fastigium of vertex as in the last species and connected as there with the deeply sulcate frontal costa, which broadens gradually below the ocellus and is there frequently punctate with black on the margins; eyes prominent, especially in the male; antennae somewhat ( $\delta$ ) or considerably ( $q$ ) shorter than the hind femora, testaceous basally, becoming ferrugineo-fuscous apically with obscure annulations. Pronotum a little longer than broad, somewhat constricted mesially, ferrugineo-testaceous, more or less and irregularly blotched with fuscous, the lateral lobes marked as in the last species; median carina somewhat cristate on the foremost lobe, but otherwise not higher than on the metazona, the scutellum moderately pronounced, and the disk of the metazona with sharp but not high elevations, particularly in the female; process of metazona usually a little obtusangulate, but sometimes rectangulate; lower posterior angle of lateral lobes somewhat retroarcuate, well rounded, nowhere angulate in either sex. Tegmina moderately slender, especially in the male, the discoidal field free of markings, the costal area dark fuscous, with a pallid patch a little beyond its widest part; wings twice as long as broad, wholly pellucid except that the costal margin is infuscated beyond the middle and the veins and crossveins in the apical region are somewhat heavily infuscated. Hind femora testaceous, apically infuscated and with a median and postmedian fuscous patch above; hind tibiae pale yellow with the slightest possible glaucous tinge, occasionally very faintly infuscated.

Length of body, $\delta, 16 \mathrm{~mm} .,+, 25 \mathrm{~mm}$.; antennae, $\delta, 8 \mathrm{~mm} ., \phi, 9 \mathrm{~mm}$.; tegmina, $\delta$, $17.5 \mathrm{~mm}$., $q, 22 \mathrm{~mm}$; hind femora, $\delta$, Iо $\mathrm{mm}$., + , $12 \mathrm{~mm}$.

24 đ, 25 \&. Lathrop, Cal., Aug. I7; Tulare, Cal., Aug. 5 ; Kern City, Cal., Aug. 4; and Lancaster, Cal., July 3 I, (Morse).

\section{Mestobregma kiowa.}

Oedipoda kiowa Thom., Ann. rep. U. S. geol. surv. terr., v, 46r ( I872).

Psinidia kiowa Thom., Rep. U. S.geol. surv. w. roo mer., v, 885 ( I875).

Mestobregma kiozesa Thom., Proc. Dav. acad. nat. sc., i, 256 ( 1876 ).

Psinidia ( Trachyrachis ) kiozera Sauss., Prodr. Oedip., I64 ( I884).

Trachyrachis kiowa Sauss., Add. prodr. Oedip., 59, I68 ( г888).

I have specimens before me from Sioux City, Iowa (Whitman), Neb raska (Dodge), Kansas (Uhler), Colorado, 7ooo', (Morrison), Ft. Collins and vicinity, Col., July, Aug. ( Baker ), Morrison, Col., Aug.9 (Scudder), Manitou, Col., Aug. 24--25 (Scudder), Pueblo, Col., Aug. 30-3I (Scudder), Canon City, Col. (Uhler), mountains of Larimer Co., Col., July I I (Baker), Garland, Col., Aug. 28-29 (Scudder), Roan Mts., Col., Aug. I 5-r 7 (Scudder), White River, Col., at Utah boundary, July 24-Aug. I3 ( Scudder), Salt Lake 
Valley, Aug. I-4 (Scudder), Spring Lake Villa, Utah Co., Utah, Aug. I-4 ( Palmer ), and Gazelle, Cal., Sept. 4 (Morse ). Besides these states, it has been reported from the Yellowstone region (Bruner), Dakota (Thomas, Bruner), and Montana (Thomas).
Of the spread specimens I have seen, all from east of the continental divide, have the base of the wings as pellucid as the distal half; while in all from west of this line, the base of the wings is washed with pale citron.

\title{
LIFE HISTORIES OF NORTH AMERICAN GEOMETRIDAE. - XIII.
}

\author{
BY HARRISON G. DYAR, WASHINGTON, D. C.
}

Synchlora glaucaria Guen. The larva has been described (as rubivora Riley) by Riley, Saunders and French but not in much detail.

$E g g$. Elliptical, strongly flattened on two sides, the flat faces concave, sunken, the edges well marked but a little rounded; side view slightly wedge shaped, the broader end truncate roundly, elevated in its center so as to be almost quite round like the narrower end, and is so except for a slight annular flattening, noticeable from side view. Surface all finely hexagonally reticulate, the reticulations not strongly raised. Pale, slightly greenish yellow, shining. Size .6 $\times .5 \times .3 \mathrm{~mm}$. Later turns pale red.

Stage I. Head round, slightly bilobed, pale brown, mottled with paler, with short, white, glandular setae; width about $.3 \mathrm{~mm}$. Body cylindrical, smooth, tubercles rather large, especially iv, which is cylindrical and produced with a conical tip. Setae white; on abdomen short with flattened enlarged tips, except iii (of joint 5) and iv (joints 6 to 9) which is very long and has a bulbous tip. This seta is sticky and bears, on its base principally, the fragments which adhere to the larva. Subdorsal setae of thorax and joint I 2 also prolonged, but much shorter than the long lateral ones. Dark brown-black mottled with ocherous, especially on joints I2 and I3, which look lighter; traces of a dark dorsal line.

Stage II. Head rounded, slightly bilobed, of the color of the body; width $.4 \mathrm{~mm}$. Body as before, the setae glandular but much shorter, iv still the longest and arising from a somewhat produced base. Color dull brown, a whitish ground speckled with brown. Skin granularly roughened. Larva rather short and thick. It becomes entirely covered with fragments of the flowers it feeds on, which adhere to the sticky setae.

Stage III. Head rounded bilobed, clypeus rather high; shagreened, setae obscure; luteous whitish, speckled with brown, heaviest near the suture and on the sides of the lobes; width $.8 \mathrm{~mm}$. Body thick and robust, dorsum slightly flattened; tubercles angularly elevated; setae small except iv, which is large and arises from an elongated tubercle. No marked lateral projections, the slight angular projections nearly alike for all the tubercles. Gray brown, densely frosted with white granules, an obscure, double, white dorsal line, divided by brown; traces of a white lateral band on the angular elevations posteriorly, on anal plate and anal feet. Tubercles pale, setae white. All the dorsum except thorax and joints I2-I3 covered with fragments of flowers which adhere to the spiny base of the short stiff seta iii. Feet pale. 

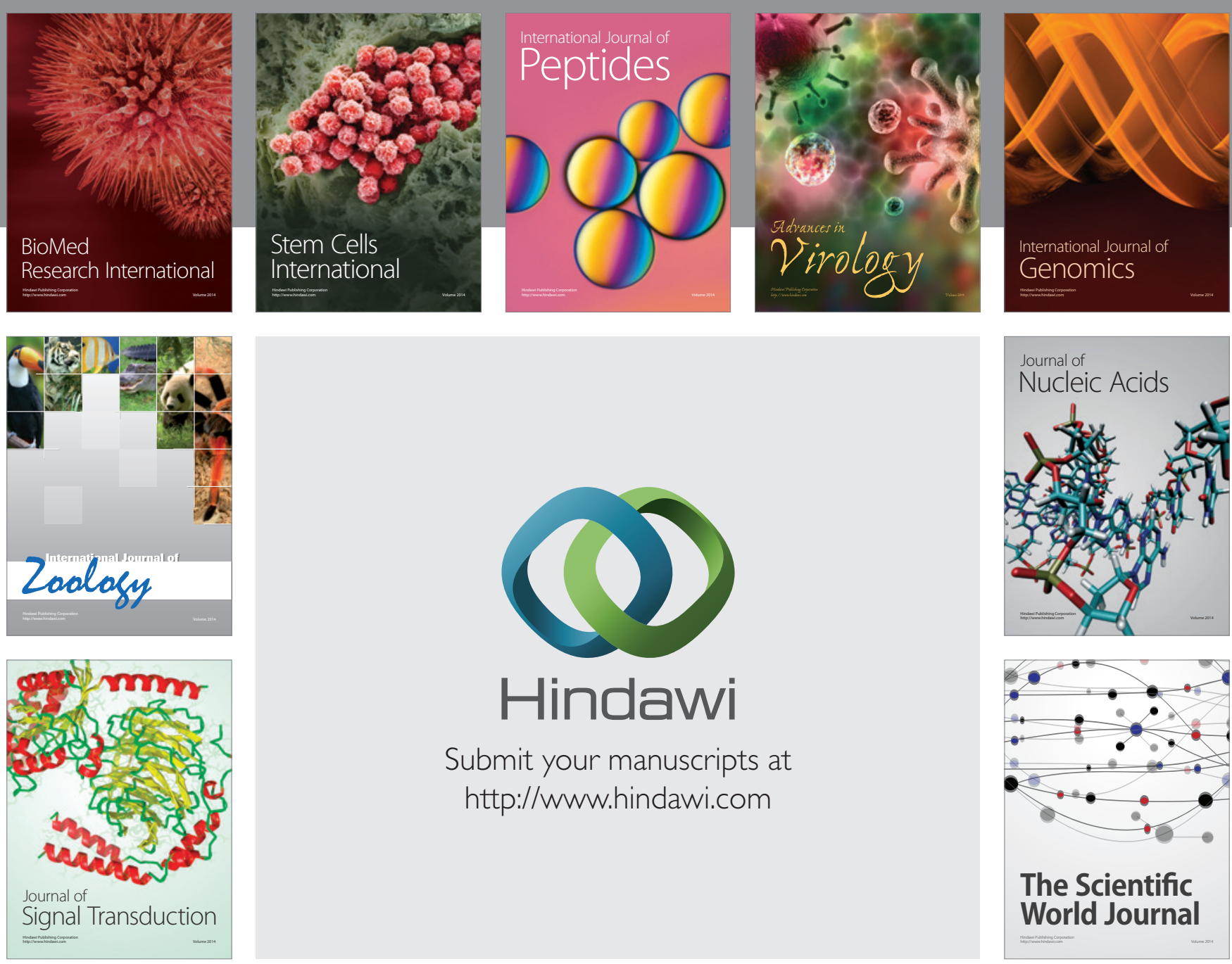

Submit your manuscripts at

http://www.hindawi.com
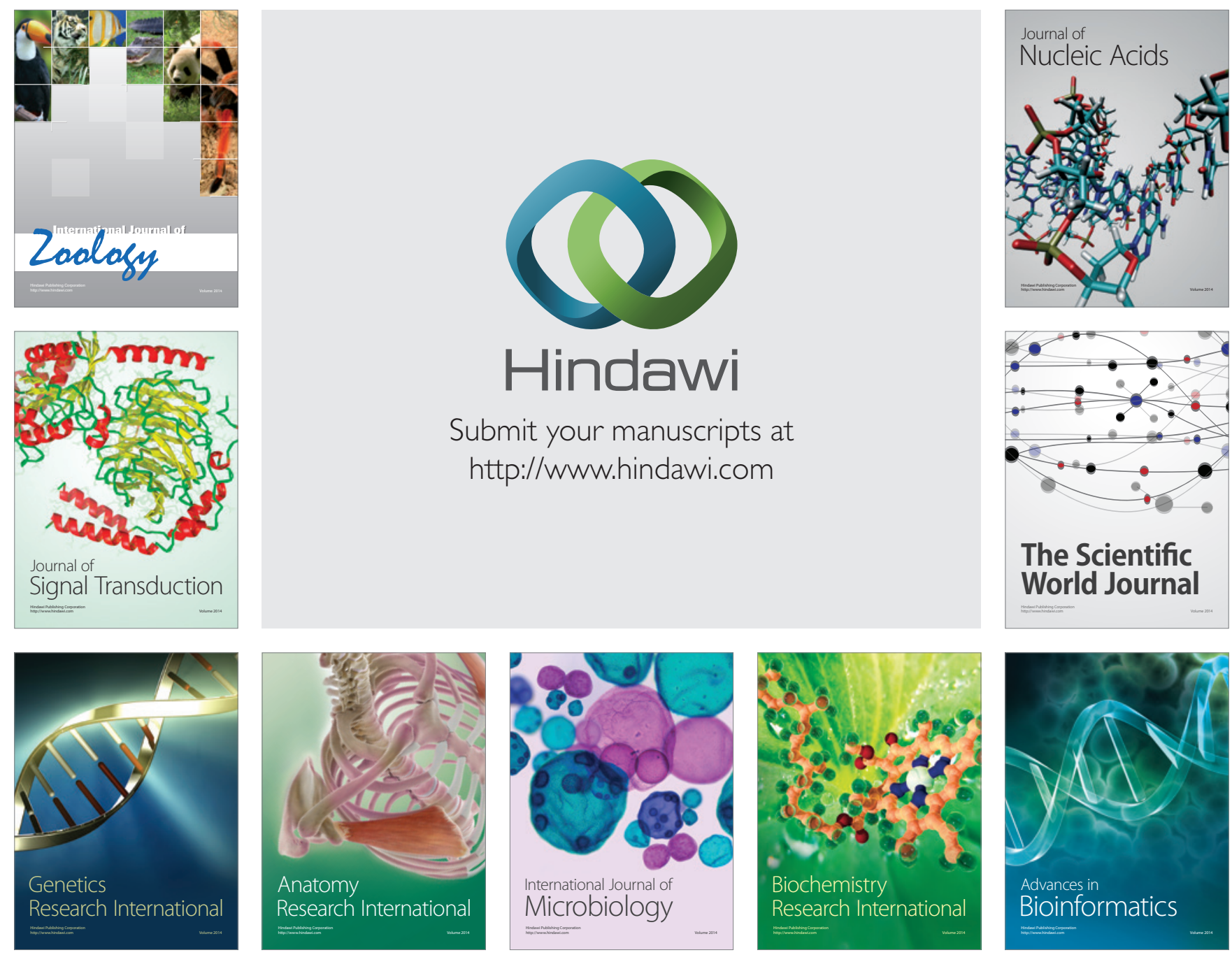

The Scientific World Journal
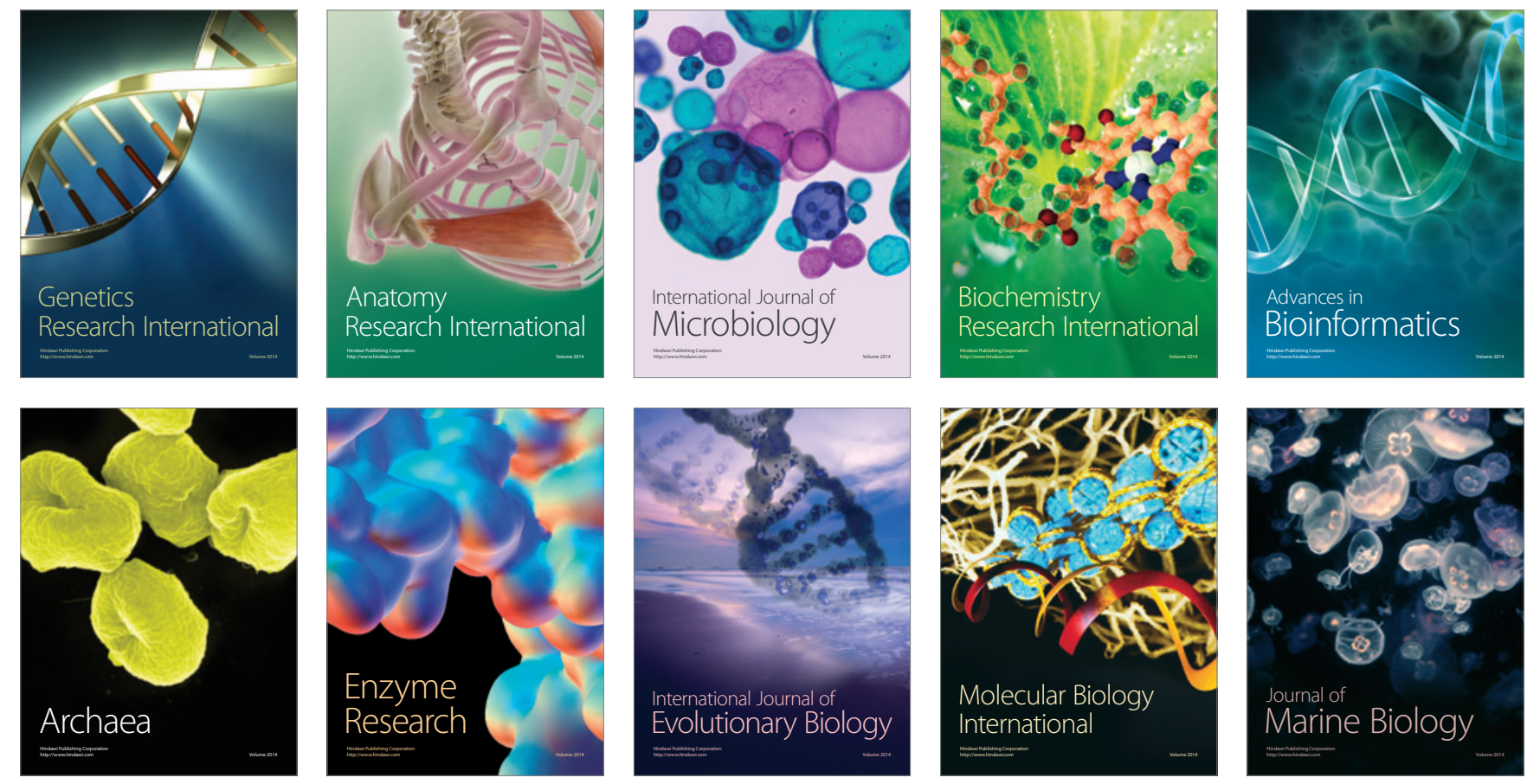